\title{
On climate variability and climate change and impact on water resources
}

\author{
Francis HS Chiew ${ }^{a}$, Ian P Prosser ${ }^{a}$ and David A Post ${ }^{\text {a }}$ \\ ${ }^{a}$ Water for a Healthy Country Flagship, CSIRO Land and Water, \\ GPO Box 1666, Canberra, ACT 2601, Australia \\ Email: francis.chiew@csiro.au
}

\begin{abstract}
Floods, droughts, and climate change are the three most important influences of climate on Australia's water resources. Australia has a very variable climate, which is amplified as even greater variability in the river flows. Climate change impact on water availability will affect people, agriculture, ecosystems, industries and many other sectors.

Climate science and modelling indicates that future winter and annual rainfall in southern Australia, where most water is consumed, is likely to decline and this will be amplified as an even bigger reduction in streamflow. The future hydroclimate of southern Australia will continue to be very variable with long wet and dry periods, but the decline in long-term average streamflow means that water resources systems need to cope with more frequent and potentially more severe droughts. As well as reducing streamflow, a warmer climate will also increase potential evaporation and hence increase the demand for water in irrigated agriculture, cities and for use by wetlands and water-dependent ecosystems. Thus climate change will not only reduce water availability but also increase the gap between supply and demand in southern Australia. Extreme rainfall events in most locations are likely to become more intense in the future, driven by a warmer atmosphere. This will lead to greater stormwater runoff and sewer overflows in urban areas, increase flood risks, and increase erosion and sediment and nutrient delivery to waterways. There may also be changes to other hydrological characteristics, but current scientific ability to predict them is limited.
\end{abstract}

This paper provides a commentary on the current state of knowledge on climate variability and climate change, and the potential impact on water resources. It describes the methods used to predict climate impact on water resources, ranging from simple rules that can be used to estimate the sensitivity of long-term average streamflow to changes in rainfall and potential evaporation, to climate and hydrological modelling to predict climate change impact on the range of hydrological characteristics. Future runoff projections across continental Australia are also presented, together with the range of uncertainty. The considerable range in future runoff projections is mainly because of the uncertainty in future regional rainfall projections under a changed climate. In the near term, future streamflow is mainly influenced by rainfall, but longer-term projections must also consider the potential changes in rainfall-temperature-runoff relationship and surfacevegetation-atmosphere feedback in a warmer and enhanced $\mathrm{CO}_{2}$ climate.

The considerable uncertainty in future hydroclimate projections makes planning adaptation measures difficult. Nevertheless, water managers and policy makers at all levels of governments in Australia are developing water strategies to cope with a variable and changing climate future. These strategies, which are not driven by climate change alone, centre on securing new water supplies, initiating demand measures, improving water delivery and water use efficiency and developing flexible and more equitable water sharing plans to cope with current and future climates.

Keywords: Climate variability, Climate change, Water resources, Climate change adaptation, Australia 


\section{INTRODUCTION}

Climate change impacts on water availability will affect people, agriculture, ecosystems, industries and many other sectors. However, planning adaptation measures is challenging because of the considerable uncertainty in the predictions of climate change impacts. This is not helped by the considerable noise in the climate change debate. The public arena is filled with informed as well as uninformed assertions and counter assertions on the human influence on climate and how this may in turn affect water resources. This also extends to the scientific literature where there are extreme points of views over-criticising or overemphasising the robustness of the science and modelling (examples on hydrology and water resources include Kundzewicz and Stakhiv (2010), Bloschl and Montanari (2010) and Beven (2011)).

Nevertheless, the large majority of researchers and practitioners interpret and use the science and modelling efforts sensibly based on the data and evidence. In this paper, we explain what we know about hydroclimate variability and climate change, the challenges in predicting future water availability and the implications for water resources adaptation to climate change.

\section{CLIMATE CHANGE, CLIMATE VARIABILITY AND WATER AVAILABILITY}

The past 20 years rank among the warmest years in the instrumental record of global average surface air temperature (since 1850). The linear warming trend is about $0.13^{\circ} \mathrm{C}$ per decade over the last 50 years and about $0.18^{\circ} \mathrm{C}$ per decade since the mid-1970s. Although this warming is not unusual in the Earth's geological history, the many lines of evidence (e.g., increasing $\mathrm{CO}_{2}$ levels, widespread warming over the land and ocean, rising sea levels, global climate modelling) suggest that the warming since the mid-20 $0^{\text {th }}$ century is very likely due to the observed increase in anthropogenic greenhouse gas concentrations (IPCC, 2007; CSIRO, 2011). Although some sectors will benefit from climate change, many sectors will need to adapt simply because existing infrastructure and systems have been built to cope with the current hydroclimate range.

Australia has a very variable climate, which is amplified as even greater variability in the river flows (Peel et al., 2004). For example, Figure 1 shows that the annual runoff averaged across the southern Murray-Darling Basin and Victoria in a wet year is more than ten times greater than the annual runoff in a dry year. The historical data also show decadal variability with very long periods of persistently wet (e.g., late 1940s to early 1980s) or persistently dry ("Federation" drought around 1900, "World War Two" drought around 1940 and the recent 1997-2009 "Millennium" drought) conditions. Large dams have been built to buffer water supplies against the high inter-annual variability, however they are unable to maintain supplies if there is a long period of low inflows. Similarly, ecosystems have evolved to cope with floods and droughts but a decade of severe drought, like the recent Millennium drought, in addition to other pressures can place them under stress. The more than 100 years of observed rainfall data and observed and modelled streamflow data are generally used to describe the inter-annual variability and the daily and seasonal characteristics of streamflow. To describe the longer-term multi-decadal variability, hydroclimate data reconstructed from palaeo records are increasingly being used (Verdon and Franks, 2006; Gallant and Gergis, 2011).

Because of the very large variability in Australian river flows, any change in the long-term average will be small compared to this variability. It is also difficult to detect a statistically significant change in the observed streamflow data above this variability. This has led some to incorrectly believe that a system designed to cope with the historical variability will be able to cope with climate change. The future climate will still be one that produces long wet and dry periods, but the projections of a decline in the long-term average streamflow in south-eastern Australia (see Figure 2 and Section 3) means that water resources systems need to be able to cope with more frequent and potentially more severe or longer droughts. For example, projecting out to 2050 and 2070, Figure 1 shows that the long-term average runoff across southern MurrayDarling Basin and Victoria under extreme climate change projections could be similar to that experienced in the recent Millenium drought.

\section{CLIMATE CHANGE IMPACT ON WATER AVAILABILITY IN AUSTRALIA}

Over the short to medium term (next 50 years), the change in streamflow will be influenced mainly by changes in rainfall. In Australia, the change in rainfall is typically amplified as a two to three times bigger percent change in streamflow, that is a $10 \%$ change in average annual rainfall will be amplified as a $20 \%$ to $30 \%$ change in average annual streamflow (Chiew, 2006). The change in long-term average streamflow can be estimated from the above climate elasticity of streamflow rule of thumb or using large-scale Budyko-Fu 
type energy and water balance equations that consider the sensitivity of long-term average streamflow to long-term average rainfall and potential evaporation (Roderick and Farquhar, 2011).

Figure 2 shows the range of projected changes to average annual runoff across Australia for a $1^{\circ} \mathrm{C}$ global warming (median warming by 2030 relative to 1990). The projections for south-eastern Australia (Chiew et al. 2009; CSIRO, 2010), Tasmania (Post et al., 2011), northern Australia (Petheram et al., 2011a) and far south-west Australia (CSIRO, 2009) come from CSIRO hydrological modelling studies and the projections elsewhere are estimated using the Budyko-Fu equation (Teng et al., 2011), all informed by the range of global climate models (GCMs) used in the IPCC Fourth Assessment Report. The considerable range in the runoff projections is mainly because of the uncertainty of future rainfall under a changed climate. In the far south-west and south-east, practically all the GCMs project a drier future and this translates to median projections of runoff declines of $25 \%$ in the far south-west and $10 \%$ in the southern Murray-Darling Basin and Victoria for a $1^{\circ} \mathrm{C}$ global warming. In the northern parts of Australia, there is little agreement between the GCMs on the direction of rainfall change. Larger changes than those shown in Figure 2 will occur as climate change continues, for example if there is $2^{\circ} \mathrm{C}$ or more warming which now seems highly likely (CSIRO, 2011).

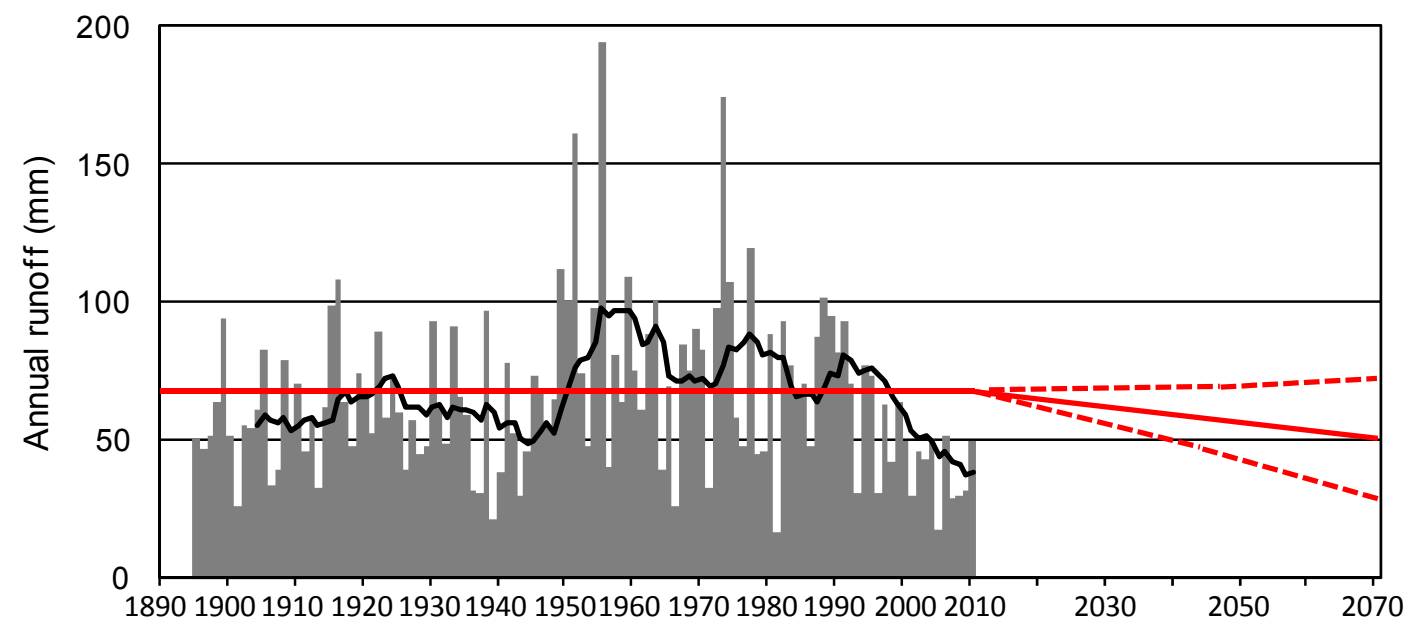

Figure 1 Modelled 1895-2010 annual time series of runoff averaged across the southern Murray-Darling Basin and Victoria (grey bars). The black line shows the low frequency variation expressed as annual runoff averaged over the previous 10 years. The red line shows the 1895-2010 average annual runoff projected to 2070 for median climate change. The two dashed red lines show the dry and wet extremes of the projected change in average annual runoff (CSIRO, 2008; Chiew et al., 2009).

\section{MODELLING CLIMATE CHANGE IMPACTS ON STREAMFLOW}

Modelling climate change impacts on streamflow is necessary to predict changes in the range of hydrologic metrics that affect different applications (e.g., daily streamflow for reservoir operation, drought sequences for water planning, and low flow characteristic and spatial flow connectivity for freshwater ecosystems). The three main modelling components involved are shown schematically in Figure 3 . The GCMs are relatively good at simulating large-scale atmospheric and ocean circulation patterns, but less so the regional climate variables. All the GCMs run by various modelling groups show global and regional warming in response to increased greenhouse gas concentrations. Up to 2030 there is little difference in the projected warming, but beyond 2050 the amount of global warming is very dependent on the greenhouse gas emission scenarios and GCMs used.

There is much less agreement in the future rainfall projections from the different GCMs. This is largely due to the difficulty in parameterising clouds and rainfall and because the coarse GCM spatial resolution cannot capture local scale characteristics. Statistical and dynamic downscaling models can help overcome this problem (Fowler et al., 2007). The statistical downscaling model relates regional patterns of rainfall and other climate variables to the large-scale drivers. The dynamic downscaling model is a fine-scale climate model 
nested inside the coarse-scale GCM, and it attempts to represent the fine-scale topography, vegetation and weather patterns. The downscaling models are often used to downscale GCM simulations to provide catchment-scale climate data to drive hydrological models (Chiew et al., 2010). Although appealing, the downscaling models also have numerous limitations. The statistical downscaling model (i) requires expert judgment to select the predictor variables that drive local rainfall, (ii) assumes that the statistical relationship developed from the historical data will remain the same in the future, and (iii) is difficult to apply directly to gridded hydrological modelling over very large regions. The dynamic downscaling model (i) uses long computer run times and (ii) produces rainfall that is difficult to realistically bias correct before using as input into hydrological models. The predictor variables used in statistical downscaling models and the physics schemes used in dynamic downscaling models are also often not the same as the known large-scale drivers of local and regional rainfall. Given these limitations and the considerable uncertainties in the future projections from GCMs, it is important to tailor the modelling effort to fit the study objectives.

There is considerable agreement between the different GCMs and downscaling models indicating that southern Australia, where most water is consumed, is on average likely to be drier in the future. There is remarkable agreement in the projection of a drier winter, and because most of the runoff in southern Australia occurs in winter, this translates to a significant reduction in average winter and therefore annual streamflows. The projection is also consistent with the patterns observed during the past several decades of the expansion in the Hadley cell and the poleward shift of the autumn and winter storm tracks and with the expected changes in the large-scale atmospheric and oceanic drivers of rainfall in south-eastern Australia and the far south-west in a warmer world (Lu et al., 2007; Shi et al., 2008; Johanson and Fu, 2009; CSIRO, 2010).
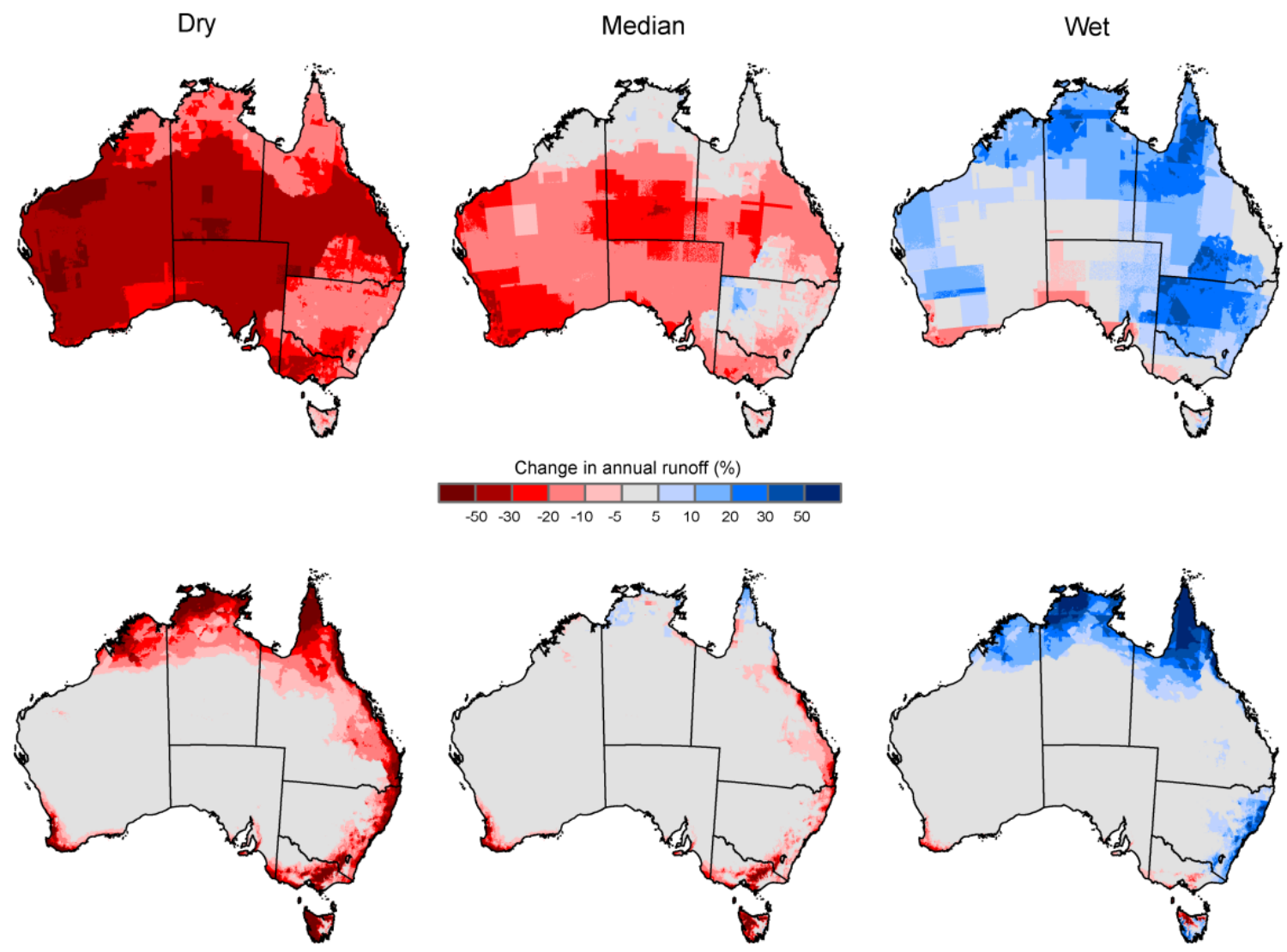

Change in annual runoff $(\mathrm{mm})$

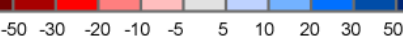

Figure 2 Change in average annual runoff for a $1{ }^{\circ} \mathrm{C}$ global warming across Australia. The top row shows percentage change and the bottom row shows change in runoff depth ( $\mathrm{mm})$. The median estimate, as well as the dry $\left(10^{\text {th }}\right.$ percentile $)$ and wet $\left(90^{\text {th }}\right.$ percentile) range of estimates are shown. The range of estimates comes from hydrological modelling informed by future climate projections from 15 GCMs. 


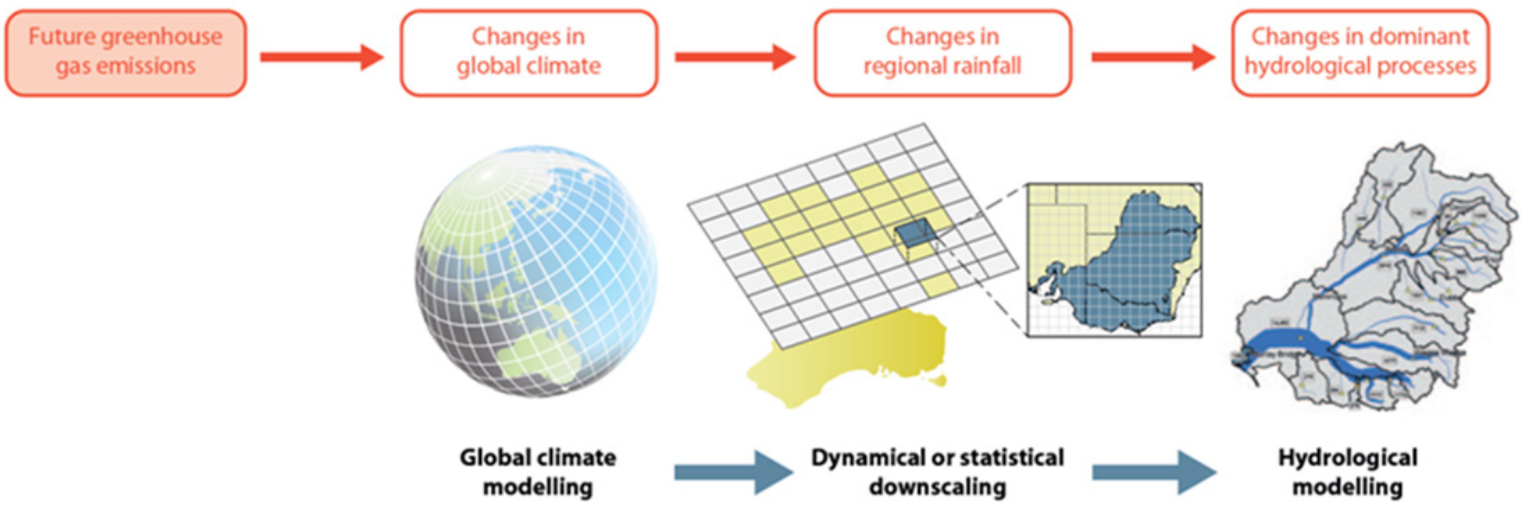

Figure 3 Modelling components for estimating future streamflow with the main sources of uncertainty shown in red.
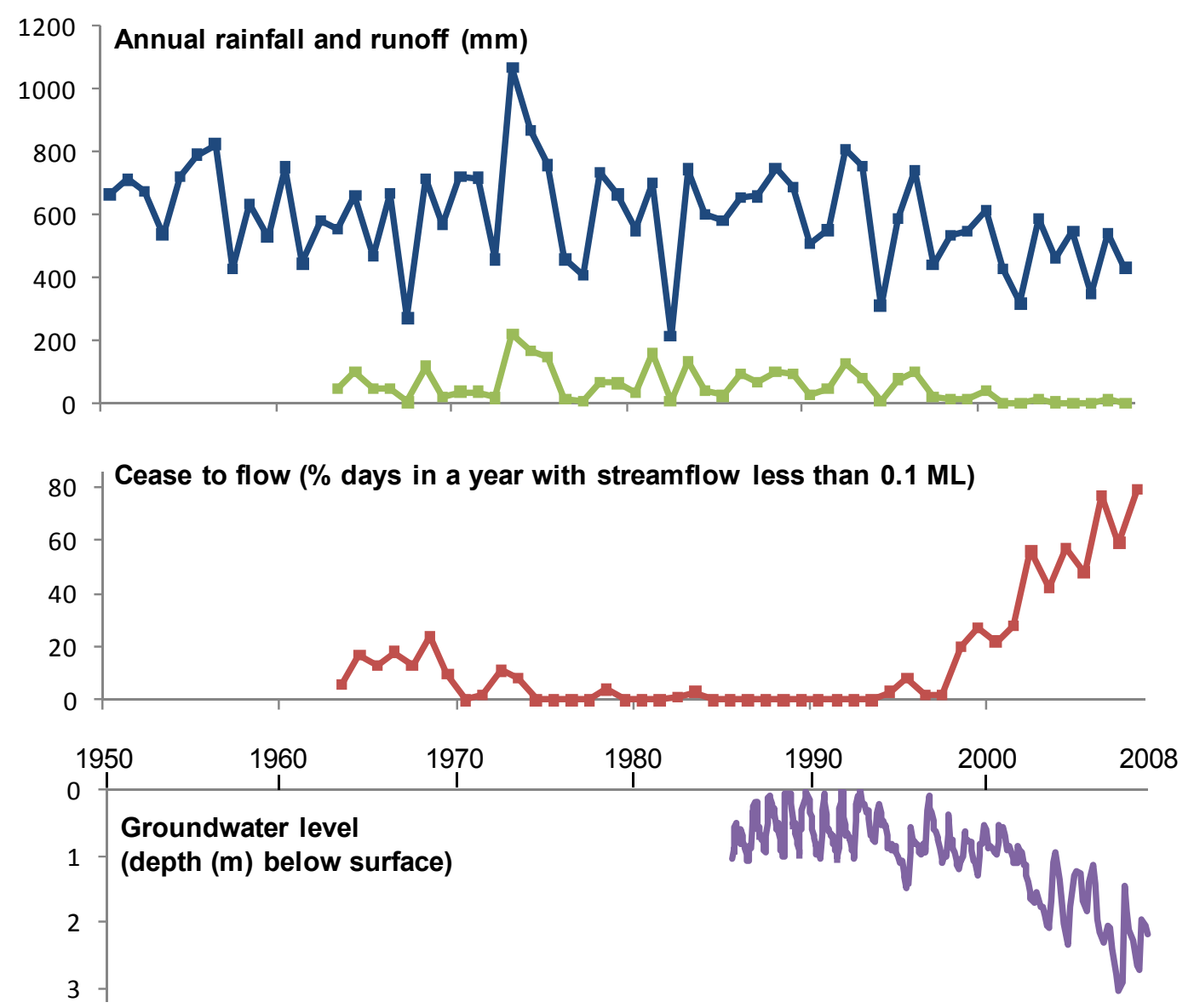

Figure 4 Hydroclimate time series in the Axe Creek catchment in north-central Victoria (typical of catchments in the southern Murray-Darling Basin and Victoria) showing changing rainfall-runoff relationship and declining groundwater levels particularly over the recent Millenium drought. 
Hydrological models calibrated against both long and recent historical data can generally be used to predict streamflow response to changes in the climate inputs (Vaze et al., 2010). However, for the longer-term projections, the hydrological models must also consider potential changes in the rainfall-temperaturestreamflow relationship and surface-atmosphere feedbacks in a warmer, drier and enhanced $\mathrm{CO}_{2}$ climate. These include potential changes in the hydrologic sensitivity to climate (particularly for large increases in temperature) (Cai and Cowan, 2008), surface-subsurface connectivity over prolonged dry periods (Petheram et al., 2011b) and forest and vegetation water use (Gedney et al., 2006). For example, Figure 4 shows the very low runoff, high number of days with no flow and declining groundwater levels in a typical catchment in the southern Murray-Darling Basin since the mid 1990s. The hydrological models must also consider other drivers of water in a changing climate, like farm dams having a greater impact on water availability during dry periods, changes in water demand and use, tree planting for carbon sequestration and forest regrowth following bushfires.

Predictions of future water availability and hydrologic characteristics will improve as a result of progress in climate and hydrological science and from tailoring and interpreting the modelling directly to the eventual hydrological application. Some of the improvements will come from (i) better understanding of changes to large-scale circulation patterns in a warmer world, (ii) better understanding of large-scale drivers of regional rainfall, (iii) weighting the GCMs on their ability to reproduce the historical observed large-scale drivers used for downscaling or the eventual runoff simulations, (iv) choosing predictor variables that are more consistent with the known large-scale drivers of rainfall, (v) better understanding of potential changes in the climaterunoff relationship and conceptualisation of dominant hydrological processes in a warmer and higher $\mathrm{CO}_{2}$ environment, and (vi) utilising new climate modelling outputs from the IPCC Fifth Assessment Report in particular the transient historical and future simulations.

\section{WATER RESOURCES ADAPTATION TO CLIMATE CHANGE}

Water resources managers in Australia are currently faced with trying to overcome the problems of decades of over-allocation of water at the same time as managing through the worse drought in a century and planning for a drier future. In this context, climate change is a major and complex challenge for water planning, but not the only challenge. As well as reducing runoff, a warmer climate will also increase potential evaporation and hence increase the demand for water in irrigated agriculture, cities and for use by wetlands and water-dependent ecosystems. Thus climate change will not only reduce water availability but also increase the gap between water supply and demand in southern Australia.

In Australia, water managers and policy makers at national, state and catchment management levels are developing sustainable water strategies to cope with a variable and changing water future. Many capital cities are moving away from traditional reliance on catchment runoff and groundwater as these sources are most sensitive to climate variability and climate change. Instead, they are diversifying by investing in desalinisation plants and water reuse. They are also reducing water demand by implementing water conservation measures and integrated urban water sensitive design. Adaptation in regional areas include spending billions to upgrade irrigation infrastructure, improve on-farm irrigation efficiency, buy back water entitlements to return water to degraded ecosystems, developing flexible and more equitable water sharing plans to cope with current and future climates, and assisting rural communities adapt to a future scenario of reduced water availability. Nevertheless, given the considerable uncertainty in future water availability predictions, water management will always need to consider scenario planning to balance between risks and rewards and develop plans that are sufficiently flexible to adapt to climate change and other drivers on water.

\section{SUMMARY}

Climate science and modelling indicates that future winter and annual rainfall in southern Australia is likely to decline and this will be amplified as an even bigger reduction in streamflow. Extreme rainfall events in most locations are likely to become more intense in the future, driven by a warmer atmosphere (CSIRO, 2011). There may also be changes to other hydrological characteristics, but current scientific ability to predict them is limited.

There is considerable uncertainty in future hydroclimate projections, making it difficult to plan adaptation measures. Nevertheless, water managers and policy makers at all levels of governments are developing water strategies to cope with a variable and changing climate future. These strategies, which are not driven by climate change alone, centre on securing new water supplies, initiating demand measures, improving water 
Chiew et al., On climate variability and climate change and impact on water resources

delivery and water use efficiency and developing flexible and more equitable water sharing plans to cope with current and future climates.

\section{REFERENCES}

Beven K (2011) I believe in climate change but how precautionary do we need to be in planning for the future? Hydrological Processes, 25, 1517-1520.

Bloschl G and Montanari A (2010) Climate change impacts - throwing the dice? Hydrological Processes, 24, $374-381$.

Cai W and Cowan T (2008) Evidence of impacts from rising temperature on inflows to the Murray-Darling Basin. Geophysical Research Letters, 35, L07701, doi:10.1029/2008GL033390.

Chiew FHS (2006) Estimation of rainfall elasticity of streamflow in Australia. Hydrological Sciences Journal, 51, 613625.

Chiew FHS, Kirono DGC, Kent DM, Frost AJ, Charles SP, Timbal B, Nguyen KC and Fu G (2010) Comparison of runoff modelled using rainfall from different downscaling methods for historical and future climates. Journal of Hydrology, 387, 10-23, doi:10.1016/j.jhydrol.2010.03.025.

Chiew FHS, Teng J, Vaze J, Post DA, Perraud J-M, Kirono DGC and Viney NR (2009) Estimating climate change impact on runoff across south-east Australia: method, results and implications of modelling method. Water Resources Research, 45, W10414, doi:10.1029/2008WR007338.

CSIRO (2008) Water Availability in the Murray-Darling Basin. A report to the Australian Government from the CSIRO Murray-Darling Sustainable Yields Project, CSIRO, Australia, 67 pp.

CSIRO (2009) Surface water yields in south-west Western Australia. A report to the Australian Government from the CSIRO South-West Western Australia Sustainable Yields Project, CSIRO, Australia,171 pp.

CSIRO (2010) Climate variability and change in south-eastern Australia: a synthesis of findings from Phase 1 of the South Eastern Australian Climate Initiative (SEACI). CSIRO, Australia, $30 \mathrm{pp}$.

CSIRO (2011) Climate Change - Science and Solutions for Australia. CSIRO Publishing, Australia, 155 pp.

Fowler HJ, Blenkinsop S and Tebaldi C (2007) Linking climate change modelling to impact studies: recent advances in downscaling techniques for hydrological modelling. International Journal of Climatology, 27, 1547-1578.

Gallant AJE and Gergis JL (2011) An experimental streamflow reconstruction for the River Murray, Australia, 17831988, Water Resources Research, 47, W00G04, doi:10.1027/2010WR009832.

Gedney N, Cox OM, Betts RA, Boucher A, Huntingford C and Stott PA (2006) Detection of a recent carbon dioxide effect in continental river runoff records. Nature, 439, 835-838.

IPCC (2007) Climate Change 2007: The Physical Basis. Contributions of Working Group 1 to the Fourth Assessment Report of the Intergovernmental Panel on Climate Change, Cambridge University Press, www.ipcc.ch.

Johanson CM and Fu Q (2009) Hadley cell widening: model simulations versus observations. Journal of Climate, 22, $2713-2725$.

Kundzewicz ZW and Stakhiv EZ (2010) Are climate models ready for prime time in water resources management applications or is more research needed? Hydrological Sciences Journal, 55, 1085-1089.

Lu J, Vecchi GA and Reichler T (2007) Expansion of the Hadley cell under global warming. Geophysical Research Letters, 34, L06805, doi:10.1029/2006GL028443.

Peel MC, McMahon TA and Finlayson BL (2004) Continental differences in the variability of annual runoff - update and assessment. Journal of Hydrology, 295, 185-197.

Petheram C, Rustomji P, Vleeshouwer J, Creswell R and Chiew F (2011a) Modelling runoff under current and future climates across the tropical savannas of northern Australia. Proceedings of the $33^{\text {rd }}$ Hydrology and Water Resources Symposium, Brisbane, July 2011, Engineers Australia, CDROM, pp. 1466-1473.

Petheram C, Potter N, Zhang L and Chiew FHS (2011b) Towards a conceptual understanding of changes in the runoffrainfall-temperature relationship. MODSIM 2011, Perth, December 2011. (This conference).

Post DA, Chiew FHS, Teng J, Viney BR, Ling FLN, Harrington G, Crosbie RS, Graham B, Marvanek S and McLoughlin $\mathrm{R}$ (2011) A robust methodology for conducting large-scale assessments of current and future water availability and use: a case study for Tasmania, Australia. Journal of Hydrology, doi:10.1016/j.jhydrol.2011.02.011.

Roderick ML and Farquhar GD (2011) A simple framework for relating variations in runoff to variations in climatic conditions and catchment properties. Water Resources Research, 47, W00G07, doi:10.1029/2010WR009826.

Shi G, Ribbe J, Cai W and Cowan T (2008) An interpretation of Australian rainfall projections. Geophysical Research Letters, L02702, doi:10.1029/2007GL032436.

Teng $\mathrm{J}$ et al. (2011) Estimation of climate change impact on mean annual runoff across continental Australia using Budyko and $\mathrm{Fu}$ equations and comparison with hydrologic model simulations. Submitted to Journal of Hydrometeorology.

Vaze J, Post DA, Chiew FHS, Perraud J-M, Viney N and Teng J (2010) Climate non-stationarity - validity of calibrated rainfall-runoff models for use in climate change studies. Journal of Hydrology, 394, 447-457, doi:10.1016/j.jhydrol.2010.09.018.

Verdon DC and Franks SW (2006) Long-term, behaviour of ENSO - Interactions with the PDO over the past 400 years. Geophysical Research Letters, 33 L07612, doi:10.1029/2005GL025052. 